\title{
Structural Change in Ethiopia: Is The Country Catching Up or Lagging Behind?
}

\author{
Fissha Asmare \\ Lecturer Wachemo university \\ Tewodros Ayalew \\ Ethiopian Airlines \\ Denekew Aman \\ Lecturer, Ethiopian Police University \\ Workineh Ayenew \\ Lecturer, Wachemo University
}

\begin{abstract}
Attaining a sustained economic growth is the prime objective of any nation in the entire world. Some countries potentially tackle this challenge and can register an extensive economic progress. However, this is true for some developed countries only. In many developing countries achieving a persistent economic growth is a big challenge. Similarly, Ethiopia has been struggling for alleviating different macroeconomic instabilities. The country is suffering from the problem of food security, income inequality and BOP deficit. But recently the country has launched a new approach to economic growth, the growth and transformation plan (GTP). Primarily, this plan is envisaged to transform the country in the class of lower middle income countries with zero level of carbon emission in 2025 . However, still the country is still challenged by different macroeconomic maladjustments. Inflation and significant level of unemployment are currently characterizing the country's economy. But, some reports of still the country's government stated that the country is going on the correct path of development. This calls an investigation on the nature of structural change in the country. Therefore, this study tries to explore structural change in the economy. It is also aimed on identifying in which sector the country achieves structural change. By using the kaldor verdon coefficient, shift share analysis, and Thrwill's law as a measure of structural change, this study revealed that, the country has show a structural change in its economic progress. Indeed, the study also indicates that, within the period between 1990 and 2013 the country is notably not far from the world economy and it is in the process of catching up. The estimated coefficient of Kaldor- Verdroon for Ethiopian economy from 2005 to 2013 is greater than 0.5 , therefore the country's manufacturing sector is operating in the dynamic economies of scale and the country have a potential of catching up in the future.
\end{abstract}

Key words: Structural change, kaldor- verdroon coefficient, GTP, Thrwill's law

\section{INTRODUCTION}

World economy has suffered from different economic, political and social problems that will hamper the living standards of the people directly or indirectly through increasing malnutrition, hunger, poverty, high unemployment and other social evils. The problems might not list ending if we look in more specific way. In one or other way countries have been struggle these problems so that they can detach their citizen from the existing miserable life. 
Ethiopia is undertaking a development strategy focused on promoting growth through high public investment. The strategy involves concentrating government expenditure on human capital and social sector and a dominant role of public enterprises in undertaking critical infrastructure investments. Associated with this the government of Ethiopia adopted a five year growth and transformation plan (GTP)in November 2010, which aimed at average annual GDP growth over $11 \%$ and achieving the Millennium Development Goals (MDGs).The main pillars of the transformation plan are raising agricultural output and productivity, promoting industrialization and investing heavily in infrastructure.

The current GTP of the country is the tool used by the ruling government as an instrument to bring structural change in the overall economy of the country.

Experiences has shown that, manufacturing as a share of GDP typically will grow from about $20 \%$ in the low income phase of development to about $40 \%$ during middle income phase of development and the employment contribution from the industry sector increases in importance for countries as they shift from low income to emerging economies.(UNDP,2012)

Structural change can be defined in many different ways. Chencry (1986) defines it as the set of changes in the composition of demand, trade, production, and factor use that takes place as per capita income increases. This definition focuses on the change in the composition of the listed economic variables. On the other hand, structural change has also defined as the change in the way that economic allocation of questions are solved over time (Magnus\&Peter, 2002)

According to this definition, structural change includes three main dimensions namely, production factor use and distribution of income. These aspects are related to the economic allocation questions, what is going to be produced, how it should be produced from it produced. Apart from per capita income growth, structural change may be the outcome of other factors like institutional change. This is due to the fact that, it sees as a function of time.

In simple terms structural change can be defined as the reallocation of labor from low productivity sectors to more dynamic (higher productivity) economic activities.

Therefore, this study tries to achieve the following main objectives

* Identify whether there is or not structural change in the economy

Assessing in which sector Ethiopia achieve a structural change

* Predicting the long run potential for structural change in the economy

\section{STYLIZED FACTS AND A BASIC HYPOTHESIS ON STRUCTURAL CHANGE AND ECONOMIC DEVELOPMENT}

In this subsection, we will present some stylized facts and a basic hypothesis on structural change and economic development.

\section{Stylized fact 1: Economic development is a process of deep structural change of the economy}

This means that economic development can be understood as a process through which a deep structural change occurs in the economy, in such a way that there is a reallocation of resources from the primary sector to the manufacturing sector, and, then, as soon as countries have achieved high levels of income per capita, from that latter sector to the service sector. So, economic development with deep structural change means that both the productive structure of the economy and the composition of net 
exports are mostly dominated by the presence of manufacturing segments that produce science-, engineering- and knowledge-based goods.

Stylized fact 2: Countries characterized by a productive structure and pattern of specialization concentrated in primary goods or natural resource-based manufactured commodities tend to direct most of the employment toward these sectors

In countries that basically specialize in primary products and natural resource-based manufactured commodities, the majority of the employment generated tends to be absorbed by these sectors. Even during the boom phases of the business cycle, the presence of a significant part of the informal employment can be dissembled and masked by a "paradox of full employment" (see Cimoli and Porcile, 2010b). From a structuralist perspective, given the dramatic level of the informality of manpower, however, the unemployment rate is usually relatively high. Not by chance, these countries tend to weakly sustain the international competitiveness of these goods based on low wages. However, whenever either the domestic currencies of these countries are overvalued in real terms or the terms of trade are temporarily favorable, wages tend to artificially increase and destroy that "spurious" kind of competitiveness (Fajnzylber, 1988). The main implication is that, by being basically determined by low relative wages, rather than by higher relative labor productivity, this pattern of static comparative advantage is not favorable to economic development (see Cimoli and Porcile, 2010a).

Stylized fact 3: The more rapidly a country is able to build and sustain a large and diversified manufacturing sector with a significant participation in total GDP and total net exports, the more rapidly it will catch up.

When several factors (lack of appropriate short-term and long-term economic policies, inadequate institutions, lack of political consensus on how to accelerate economic development, etc.) prevent countries from developing a large and diversified manufacturing industry, they tend to specialize in goods with static comparative advantage, especially in labor intensive and natural resource-based goods. Since these sectors have low capacity of generating and diffusing technical progress as well as of taking advantage of dynamic economies of scale, the technological gap increases to such a magnitude that the development process tends to become locked-in in a regressive technological path (see Arthur, 1989). So, the catching up process is more rapid when countries are successful in producing structural change and redirecting most of their exports towards science-, engineering- and knowledgebased industries. Hausmann, Hwang and Rodrik (2007) showed that "what you export matters". That is to say, countries whose export basket has a significant part composed of products of high technological sophistication tend to show higher rates of economic growth in the long run. By contrast, if their productive structure and pattern of specialization is dominated by labor intensive and natural resource-based goods, countries tend to experience a falling behind path.

Basic hypothesis on structural change and economic development: The more a country directs its productive structure and net export basket to very diversified goods, with a major presence of the science-, engineering- and knowledge-based sectors, the larger will be its degree of intensity of structural change.

This above hypothesis depends on the so-called Thirlwall's Law (see Thirlwall, 1979), as follows:

$$
Y_{i} / Y_{i}^{*}=E_{x} / \prod_{m}
$$


Where $\boldsymbol{Y} \boldsymbol{i}$ is the rate of economic growth in the domestic country; $\boldsymbol{Y} \mathbf{i} *$ is the rate of world economic growth; $X \mathrm{e}$ is the income elasticity of demand for exports; and $\Pi_{\mathrm{m}}$ is the income elasticity of demand for imports.

Thirlwall's Law suggests that the convergence of the rate of economic growth in a particular country (say, a developing country) to the world economic growth depends on the ratio between the income elasticity of demand for exports and income elasticity of demand for imports. In other words, if the income elasticity of demand for exports increases above the income elasticity of demand for imports, economic development is sustained because economic growth will not be constrained by balance of payments constraints in the long run. (André, N.,Carmem, F., and Eliane, A.,2013)

\section{Measures of Structural Change}

\section{METHODOLOGY AND ANALYSIS}

Though it is somehow trivial to get one unique measurement of structural transformation but it is possible to use its indicators for the purpose of measurement. Thus, based up on the available related literatures we have tried to measure indicators of structural change and therefore to proxy structural change by these values.

The following measures are used as main analytical tools.

\section{Kaldor- Verdroon Coefficient}

The theoretical framework of this paper is based on Kaldor and Thirlwall theories on the basic driving forces of the behavior of productivity and economic growth in the long run. From the Kaldorian view, we will base our work on the hypothesis that the main sources of the behavior of the aggregate productivity come from the manufacturing sector. The main empirical justification is that this sector, compared to the primary and service sectors, operates under significant static and dynamic economies of scale, such that it has the highest capacity to disseminate its gains from productivity to the economy as a whole. By anchoring on this Kaldorian hypothesis, we also show that the more a country is able to construct a large and diversified manufacturing sector during its catching up process, the more will be its capacity to sustain high rates of economic growth in the long run. In the literature on economic development, this relationship between the real output of the manufacturing industry and its positive effects on the productivity of the economy as a whole is known as the KaldorVerdoorn Law.

This law or coefficient was originally by verdroon (1949) and used by Kaldor (1966) according to the following equation.

$$
\mathbf{P}=\mathbf{a}+\mathbf{b} \mathbf{Q}
$$

Where p- is exponential growth rate of labor productivity in the manufacturing sector, q- is the exponential growth rate of manufacturing output- is the Kaldoor Verdroon coefficient. For having an equivocal evidence of the existence of static and dynamic economic of scale in manufacturing sector there must be a statistically significant relationship between $\mathrm{p}$ and $\mathrm{q}$ with regression coefficient less than one and for the existence of constant returns to scale to be rejected the Kaldoor Verdroon coefficient must be statistically different from zero.

Kaldoor implicitly considered that a coefficient near 0.5 as idealistically good for a developing country sustaining a catching up process (Kaldor, 1996). This is because countries like Germany and USA, during the period in which they were close to the catching up with the UK, 
between the last quarter of the $19^{\text {th }}$ century and early $20^{\text {th }}$ century showed a K-V coefficient of 0.42 and 0.49 respectively. (Mccombic\&thirlwall, 1994)

\section{Thirlwall's Law}

This Kaldorian theoretical framework will additionally be complemented by the Thirlwall hypothesis on the importance of a country to have an income elasticity of demand for exports above the income elasticity of demand for imports if the country intends to sustain economic growth without facing balance of payments constraints (Thirlwall's Law). This hypothesis makes it clear why it is important for a developing country to have not only a large and diversified export composition, but also the majority of its net exports (exports minus imports) basket composed of goods of high income elasticity of demand in the long run

We have estimated the income elasticity of demand for export and import of Ethiopian economy from 1990-2013.

The econometric model is actually follows cimoli, porcile, and rovira (2010). Who implemented two regressions for estimating the demand functions for import and export respectively according to the following specifications?

$$
\begin{aligned}
& M_{t}=c+\omega\left(\operatorname{Rer}_{t}\right)+\pi\left(Y_{t}\right)+\varepsilon_{t} \\
& X_{t}=c+\varphi\left(R E R_{T}\right)+\epsilon\left(Y_{t}^{*}\right)+\varepsilon_{t} .
\end{aligned}
$$

Where,

Mt- growth rate of import exogenous constant term, $\omega$ - price elasticity of demand for imports, $\operatorname{Rer}_{t}$ - growth rate of real exchange rate, $\varphi$ the price elasticity of demand for exports, $\pi$ - income elasticity of demand for imports, $Y_{t}$ - the growth rate of domestic real GDP, $X_{t}$ - the growth rate of export, $\in$ - income elasticity of demand for export, $Y_{t}^{*}$ - the growth rate of world economy, $\mathrm{t}$ the respective quarterly time, $\varepsilon_{t}$ - white noise error term.

According to Thirlwall (1979) and Mc combie \&Thirlwall (1994) the income elasticity of demand for import and export reflect competitive factors associated with productive structure of the whole economy. This elasticity's are determined by content and other characteristics of both imported and exported commodities like, degree of technological sophistication, the level of product differentiation, and domestic capacity to respond to changes in global demand.

Countries whose net import structure is characterized by higher technological content than the export one have a higher income elasticity of demand for import than export. In other words, if countries have higher income elasticity's of demand for import than export then they are characterized by high import structure of technological content.

These indicators tend not only to show the countries technological gap with respect to the international technological frontier, to put the country to a unsustainable economic growth trajectory .i.e. it will face major external constraints to show in the long run. This is actually measured by Thirlwall's law,

$$
\frac{Y i}{Y *}=\frac{\epsilon x}{\in m}
$$


Where $Y i$ is the rate of economic growth in the domestic country; $Y^{*}$ is the rate of world economic growth; $E x$ is the income elasticity of demand for exports; and $E m$ is the income elasticity of demand for imports.

Thirlwall's Law suggests that the convergence of the rate of economic growth in a particular country (say, a developing country) to the world economic growth depends on the ratio between the income elasticity of demand for exports and income elasticity of demand for imports. In other words, if the income elasticity of demand for exports increases above the income elasticity of demand for imports, economic development is sustained because economic growth will not be constrained by balance of payments constraints in the long run.

\section{SHIFT SHARE ANALYSIS}

One evidences for the existence of structural transformation is the transformation of resources like labor from the low productivity sector to a highly productive sector of an economy. When there is structural change the low productivity sector will be benefited by transforming labor in its higher productivity counterpart. Associated with this shift share analysis will be used to decompose the inter sector labor productivity and labor mobility.

Let $\mathrm{P}$ denote aggregate labor productivity

$$
\begin{gathered}
P=\sum_{i} \sigma_{i} p_{i}, \quad i=1,2,3, \ldots . . \\
\dot{\mathrm{P}}=\frac{1}{\mathrm{P}_{0}}\left[\sum_{\mathrm{l}=1}\left(\sigma_{\mathrm{lt}}-\sigma_{\mathrm{10}}\right) \mathrm{p}_{\mathrm{10}}+\sum_{\mathrm{l}=1}\left(\mathrm{p}_{\mathrm{lt}}-\mathrm{p}_{\mathrm{l} 0}\right) \sigma_{10}+\sum_{\mathrm{l}=1}\left(\sigma_{\mathrm{lt}}-\sigma_{10}\right) \sum_{\mathrm{l}=1}\left(\mathrm{p}_{\mathrm{lt}}-\mathrm{p}_{\mathrm{l} 0}\right)\right]
\end{gathered}
$$

Where; $\mathrm{p}_{0}$ aggregate labor productivity at time $0 . \delta i$ is the employment share of sector in total employment, and $p i$ denotes labour productivity in sector $\mathrm{i}: \mathrm{Pi}=\frac{V A i}{L i}$ where VAi and $\mathrm{Li}$ are value added and employment in sector i respectively

Following Ferede and Kebede, 2015 the right hand side of the above equation has three main parts

- The first term is employment effect - it shows the weighted productivity effect of labor reallocation across sectors. Positive value of this term shows that the positive relationship between employments shares and productivity levels. If industries with higher productivity attract more labor resource it will be positive and it will be negative if industries with higher productivity attract less labor resource. In general it shows the development path that shifts resource (e.g. labor) across sectors.

- The second term is the weighted within sector productivity- it represents the contribution of within sector labor productivity to overall labor productivity growth.

- The third term is the interaction effect of both employment and productivity changes. It shows the contribution of change in allocation of labor across sectors and change in productivity within individual sectors to aggregate labor productivity growth.

\section{SHIFT SHARE ANALYSIS}

\section{RESULTS AND DISCUSSIONS}

Here below we have tried to present the decomposed results of total labor productivity growth for periods 2005 and 2013. The within sector productivity growth contributes positively for the aggregate labor productivity while, structural change effects contributes negatively. This result is in line with pedro, 2014, Ferede and Shiferaw,2015 
When we look the contributions of each component, the negative values of employment effect is the reflection of the inability of high productivity sectors to employ (attract) more labor. In the same fashion the negative value of interaction effect indicates that sectors with fast growing labor productivity cannot maintain their share in total employment.

There is also a sectoral variation in terms of labor transfer. All the 3 sectors have appositive value of within sector labor productivity growth, but the contribution of the service sector is very large which accounts $61.9 \%$ of the total within sector productivity growth.

The employment and interaction effects of the manufacturing and agricultural sectors are negative while the only positive value is accompanied with the service sector. This shows that labor is shifted from productive sectors to service.

The structural change component is negative indicating that, labor moved to sectors with lower productivity levels such as from manufacturing to informal urban activities and this will hinder economic growth.

\begin{tabular}{|l|l|l|l|}
\hline & \multicolumn{2}{|l|}{ Structural change effect } \\
\hline Sectors & $\begin{array}{l}\text { Within-sector } \\
\text { productivity growth }\end{array}$ & Employment effect & Interaction effect \\
\hline Agriculture & 0.031 & -0.005 & -0.011 \\
\hline Service & 0.101 & 0.0007 & 0.0014 \\
\hline manufacturing & 0.031 & -0.0012 & -0.0024 \\
\hline Total & 0.163 & -0.0055 & -0.012 \\
\hline
\end{tabular}

Source; own computation based on CSA national labor force survey $(2005,2013)$

\section{Estimating Thirlwall's Law for Ethiopian economy since 1990}

Before undertaking the econometric analysis all the variables have tasted for stationary. The augmented decay fuller (ADF) test for unit roots revels that all the variables are stationary at levels so we have directly use all the variables without any adjustment for our analysis. As we have looked in the table below since 1990 to 2013 the country's export has been responsive highly for development of world economy than the international market price fluctuation. Because the price elasticity of demand for export is lower while the income elasticity of demand for export is actually very high. The two variables found to be significant at $10 \%$ and the convectional levels of significant respectively.

The lower price elasticity of demand for export relative to income elasticity of demand for export may be accompanied with the inability of the country's economy to give an immediate response for international market price fluctuation. 

Dependent Variable: GX
Method: Least Squares
Sample (adjusted): 19912013
Included observations: 23 after adjustments

\begin{tabular}{ccccc}
\hline \hline Variable & Coefficient & Std. Error & t-Statistic & Prob. \\
\hline \hline C & 31.86178 & 9.929445 & 3.208818 & 0.0044
\end{tabular}

Price elasticity of

demand for export
$(\varphi)$
2.208489
0.368763
5.988908
0.0000

Income elasticity of

demand for

$$
\begin{array}{llllll}
\operatorname{export}(\varepsilon) & 7.082960 & 4.073121 & 1.738952 & 0.0974
\end{array}
$$

\begin{tabular}{lrll}
\hline \hline R-squared & 0.651804 & Mean dependent var & 16.27393 \\
Adjusted R-squared & 0.616984 & S.D. dependent var & 43.58698 \\
S.E. of regression & 26.97523 & Akaike info criterion & 9.548823 \\
Sum squared resid & 14553.26 & Schwarz criterion & 9.696931 \\
Log likelihood & -106.8115 & Hannan-Quinn criter. & 9.586072 \\
F-statistic & 18.71944 & Durbin-Watson stat & 2.397670 \\
Prob(F-statistic) & 0.000026 & & \\
\hline \hline
\end{tabular}

I contrast to the price elasticity of demand for import income elasticity of demand for import is higher. They are 0.69 and 1.106 respectively and statistically significant at the convectional levels of significance.

The main implication behind the lower value of the price elasticity of demand for import is the fact that our import is highly dominated by necessary products in which we cannot change the amount we import though the price is fluctuated. 
Dependent Variable: GM

Method: Least Squares

Sample: 19902013

Included observations: 24

\begin{tabular}{lcllc}
\hline \hline \multicolumn{1}{c}{ Variable } & Coefficient & Std. Error & t-Statistic & Prob. \\
\hline \hline \multicolumn{1}{c}{ Price elasticity of } & & & & \\
demand for import & & & & \\
\multicolumn{1}{c}{$(\psi)$} & 0.696733 & 0.180025 & -3.870188 & 0.0009 \\
Income elasticity of & & & & \\
demand for import $(\pi)$ & 1.106926 & 0.388015 & 2.852792 & 0.0095 \\
\multicolumn{1}{c}{ C } & 4.349011 & 4.030905 & 1.078917 & 0.2929 \\
\hline \hline R-squared & 0.559371 & Mean dependent var & 11.15722 \\
Adjusted R-squared & 0.517407 & S.D. dependent var & 21.38972 \\
S.E. of regression & 14.85921 & Akaike info criterion & 8.351585 \\
Sum squared resid & 4636.719 & Schwarz criterion & 8.498842 \\
Log likelihood & -97.21903 & Hannan-Quinn criter. & 8.390653 \\
F-statistic & 13.32958 & Durbin-Watson stat & 2.300638 \\
Prob(F-statistic) & 0.000183 & & & \\
\hline \hline
\end{tabular}

Now by combining the results of the above two tables we will generate a value that can measure structural change. This is what we call Thirlwall's law. It measures the ratio between the income elasticity of demand for export and income elasticity of demand for import. As indicated in the table above the ratio between the two is very high in Ethiopia with in the period between 1990 and 2013.this indicates that the country is notably not far from the world economy and it is in the process of catching up.

These indicators tend not only to show the countries technological gap with respect to the international technological frontier, to put the country to a unsustainable economic growth trajectory .i.e. it will face major external constraints to show in the long run. If the ratio between the two is less than one then it not only indicates that the country has a high technological gap with respect to the international technological frontier, but it also indicates the future potential of the country for catching up .i.e. it shows whether the country's economic development will be hindered by external constraints or not. Associated with this, since this value for Ethiopia is very high, the country has enough potential for growth and even further catching up. 


\begin{tabular}{|l|l|l|l|}
\hline Period & \multicolumn{1}{|c|}{$\begin{array}{c}\text { Income elasticity of } \\
\text { demand } \\
\text { for Ethiopian exports }(\varepsilon x)\end{array}$} & $\begin{array}{l}\text { Income elasticity of demand } \\
\text { for Ethiopian imports }(\pi M)\end{array}$ & \multicolumn{1}{|c|}{ Thirlwall's Law } \\
\hline $1990-2013$ & 7.082960 & 1.106926 & 6.398 \\
\hline
\end{tabular}

\section{Kaldor- Verdroon Coefficient}

Even though there is data problem in estimating this coefficient, but given the data problem as a limitation and in combination with Thirlwall's law coefficient it gives a sound result.

The coefficient of $\mathrm{q}$ in the following equation shows that whether the manufacturing sector of the economy is operating in the dynamic economies of scale or not. To say the sector is operating in the dynamic economies of scale the coefficient should be greater than 0.5. This coefficient also indicates that the future potential of the economy for catching up. In line with this the estimated coefficient for Ethiopian economy from 2005 to 2013 is greater than 0.5, therefore the country's manufacturing sector is operating in the dynamic economies of scale and the country have a potential of catching up in the future.

$$
p=3.56+0.664750967524 q
$$

\section{CONCLUDING REMARKS}

This paper assessed whether Ethiopian economy attains structural change or not. It also tries to address the position of the country from the world economic as well as technological frontier. i.e. is the country catching up or lagging behind.

Many researchers have revealed that the country is attaining structural transformation which is from the agricultural sector to the service sector. For instance, by taking the employment perspective measure Pedro, 2014, Ferede\&Shiferaw, 2015, have showed that the country is attaining a structural transformation from the agricultural sector in to the service sector.

Similarly by taking the export composition and employment perspective measures this paper also proves the existence of structural change in Ethiopia. Not only this but also it tries to forecast the long run potential of the country for future economic progress by estimating the so called Kaldor Veldor's coefficient. From the general analysis of the paper the following conclusions are drawn.

In terms of employment perspective, there is a sectoral variation in labor transfer. All the 3 sectors have appositive value of within sector labor productivity growth, but the contribution of the service sector is very large which accounts $61.9 \%$ of the total within sector productivity growth.

The employment and interaction effects of the manufacturing and agricultural sectors are negative while the only positive value is accompanied with the service sector. This shows that labor is shifted from productive sectors to service.

The value of the Thriwilias law shows that, as the country is attaining structural change and, is also in the process of catching up. The coefficient for the period between 1990 and 2013 is found to be 6.398 which are higher than the threshold level of 1 . 
The countries potential for catching up is also addressed by estimating the Kaldoor Verdon coefficient. As long as this coefficient is greater than 0.5 , which is 0.6 in Ethiopia, the country is in the process of catching up.

\section{References}

André Nassif, Carmem Feijó and Eliane Araújo(2013). Structural Change And Economic Development: Is Brazil Catching Up Or Falling Behind?

Cimoli M, Porcile G and Rovira S (2010). Structural Change and BOP-Constraint: Why did Latin America Fail to Converge. Cambridge Journal of Economics 34: 389-411.

Hausmann R, Hwang J and Rodrik D (2007). What you Export Matters. Journal of Economic Growth, 12 (1):1-25. International Monetary Fund (IMF, 2014).The Federal Democratic Republic Of Ethiopia Selected Issues Paper

Kaldor N (1966). Causes of the slow rate of economic growth of the United Kingdom. An inaugural lecture. Cambridge: Cambridge University Press.

Tadele F, Shiferaw K. (2015) Economic growth and employment patterns, dominant sector, and firm profiles in Ethiopia: Opportunities, challenges and Prospects

Thirlwall AP (1979). The balance of payments constraint as an explanation of international growth rates differences. Banca Nazionale del Lavoro Quarterly Review, Vol. 128.

UNDP Ethiopia (2014) Ethiopia Quarterly Key Economic and Social Indicators produced by the Policy Advisory Unit

Verdoorn PJ (1949). Fattori che regolano lo sviluppo della produttivitá del lavoro. L'Industria 